\title{
CTLA-4 checkpoint blockade in breast cancer, a case in point report
}

\author{
Chiara Dellepiane ${ }^{1 *}$, Michela Lia², Mario Roberto Sertoli ${ }^{1}$ \\ From Breast Cancer Immunotherapy Symposium (BRECIS), part of the Sidra Symposia Series, held in partner- \\ ship with the Society for Immunotherapy of Cancer \\ Doha, Qatar. 13-14 April 2015
}

A patient concomitantly affected by breast cancer and melanoma is presented in order to contribute to the ongoing debate on breast cancer immunotherapy $[1,2]$. In 1996 the patient was operated on for left early breast cancer and treated with adjuvant radiotherapy and 5 years Tamoxifen. In 2009 biochemical progression and bone metastases appeared so Letrozole hormonal therapy was carried out, ensuing in clinical stabilization. In 2010, a left arm cutaneous melanoma was excised (pT4a Breslow $4.5 \mathrm{~mm}$ ), and axillary nodal dissection detecting an involved node. Because of subsequent intransit metastases, the patient underwent chemohyperthermic perfusion, reaching a dermic complete response (CR). Suddenly melanoma progressed in the lung and liver, as confirmed by ultrasound driven biopsy. Chemotherapy (DTIC) was given, achieving visceral partial response. At this point Ipilimumab [3] was available and CR of liver, lung, and dermic metastases was obtained after 4 cycles, while bone lesions remained stable and considered breast cancer. Four months later novel liver metastases appeared and biopsy unexpectedly confirmed their breast cancer origin. The patient after unsuccessful chemotherapy, finally died of liver failure, without evidence of melanoma metastases. This very special case shows the impressive discrepancy in response to CTLA4 check-point therapy between melanoma and breast cancer.

\section{Authors' details}

'Clinic of Medical Oncology, IRCCS SAN MARTINO IST, Genoa University, Genoa, Italy. ${ }^{2}$ EORTC, Bruxelles, Belgium.
Published: 14 August 2015

\section{References}

1. Emens $L A$ : LA Breast cancer immunobiology driving immunotherapy: vaccines and immune checkpoint blockade. Expert Rev Anticancer Ther 2012, 12(12):1597-611, doi: 10.1586/era.12.147. Review.

2. Nanda R, Chow LQ, Dees EC, et al: A phase Ib study of pembrolizumab (MK-3475) in patients with advanced triple-negative breast cancer. SABCS 2014 San Antonio, Texas; 2014, Abstract S1-09.

3. Hodi FS, O'Day SJ, McDermott DF, Weber RW, Sosman JA, Haanen JB, Gonzalez R, Robert C, Schadendorf D, Hassel JC, et al: Improved survival with ipilimumab in patients with metastatic melanoma. $N$ Engl J Med 2010, 363:711-723.

\section{doi:10.1186/2051-1426-3-S1-O4}

Cite this article as: Dellepiane et al: CTLA- 4 checkpoint blockade in breast cancer, a case in point report. Journal for ImmunoTherapy of Cancer 2015 3(Suppl 1):04.
Submit your next manuscript to BioMed Central and take full advantage of:

- Convenient online submission

- Thorough peer review

- No space constraints or color figure charges

- Immediate publication on acceptance

- Inclusion in PubMed, CAS, Scopus and Google Scholar

- Research which is freely available for redistribution
C Biomed Central 